\title{
A Relational Analysis of State Law and Folk Law in the Bongkoran Agrarian Conflicts, Banyuwangi Regency, East Java, Indonesia
}

\section{Umar Sholahudin 1,* (D) Hotman Siahaan 2, (1) and Herlambang P. Wiratraman ${ }^{3}$}

${ }^{1}$ Doctoral Program of Social Science, Faculty of Social and Political Sciences,

Universitas Airlangga, 60286, Surabaya, Indonesia

2 Department of Sociology, Faculty of Social and Political Sciences,

Universitas Airlangga, 60286, Surabaya, Indonesia

${ }^{3}$ Department of Law and Development Science, Faculty of Law,

Universitas Airlangga, 60286, Surabaya, Indonesia

* Corresponding Author: umar.sholahudin@gmail.com

\section{ARTICLE INFO}

Publication Info:

Research Article

How to cite:

Sholahudin, U., Siahaan, H., E

Wiratraman, H. P. (2020). A

Relational Analysis of State Law

and Folk Law in the Bongkoran Agrarian Conflicts, Banyuwangi Regency, East Java, Indonesia.

Society, 8(2), 419-436.

DOI: 10.33019/society.v8i2.195

Copyright (C) 2020. Owned by Author(s), published by Society

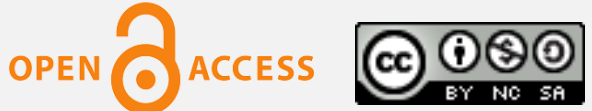

This is an open-access article.

License: Attribution-

NonCommercial-ShareAlike (CC BY-NC-SA)

\section{ABSTRACT}

Apart from having a socio-economic dimension, agrarian conflicts in Bongkoran, Banyuwangi Regency, East Java Province, Indonesia, also have a legal dimension. There is a dualism of law that is conflictual in terms of land tenure and use claims. One party, the government, and corporations rely on legalistic-positivistic state laws, while local people rely on folk law, namely informal laws that have existed, lived, and developed in communal society for generations. This research focuses on how the sociological perspective of law analyzes the legal conflicts that occur in Bongkoran agrarian conflict, particularly between state law and folk law. This research used a qualitative method with a legal sociology perspective. The research subjects were farmers/people of Bongkoran, Community Legal Advisors (CLA), Government (Local Government, National Land Agency, and Police), and corporate elements (PT Wongsorejo). Informants were selected using a purposive sampling technique, based on certain considerations that can be recognized beforehand, namely recognizing and understanding the problem under this research. Data collection was conducted through observation, in-depth interviews, and documentation. The collected data were analyzed qualitatively by referring to the perspectives that have been presented. The results indicated that the resolution of agrarian conflicts in Bongkoran requires the implementation of laws that are more just for local communities. The implementation of the laws is not only based on rigid articles in

Copyright (C 2020. Owned by Author(s), published by Society. This is an open-access article under the CC-BY-NC-SA license. 
A Relational Analysis of State Law and Folk Law in the Bongkoran Agrarian Conflicts, Banyuwangi Regency, East Java, Indonesia

Received: June 14, 2020;

Accepted: August 13, 2020;

Published: September 30, 2020; the law, but it needs attention to the socio-cultural and historical context of the community. The dominance of state law over folk law in agrarian conflicts results in the practice of subjugation of state law to folk law, both persuasively and repressively. Therefore, to minimize the tension and conflict between state law and folk law in agrarian conflicts, it is necessary to have a new understanding of the relationship between the two laws. The existence and enforcement of folk law are used as a complementary element in normative aspects that have not been regulated in state law.

\section{Keywords: Agrarian Conflict; Bongkoran; Folk Law; Legal Relations; State Law}

\section{Introduction}

One of the dimensions in the structural agrarian conflict in Indonesia is the legal dimension. The two legal systems with different sources and characters that cover land conflicts and each of them have an existence, they are state laws and folk laws or known as legal dualism. In general, the source of agrarian conflicts is mutual claims over land ownership and utilization. The state and people have a different basis for legitimacy. On the other hand, the state, in this case, the government claims ownership and utilization rights of the land-based on legal-formal aspects or state law (de jure). Meanwhile, local people ownership and utilization rights of the land-based on their customary laws that already exist, live, and apply in local communities (de facto) (Afrizal, 2006; 2018).

Rachman (2016) stated that the dominance of the land tenure system comes from state law has to lead the main cause of agrarian conflict. In this case, the state unilaterally provides great services to capital owners in developing their business to manage land and other natural resources including forest products. Meanwhile, the people's rights as a local community who have lived for generations and developed a separate system to manage land and other natural resources are ignored and simply violated. It is not only the domination of a legal system (state law) but also the state domination practice over the people used elements of structural violence due to the state apparatus as the main source.

Agrarian conflict is inseparable to the power relations between interrelated three main actors; the state, the capital owners (corporations), and local people (Afrizal, 2006; 2018). Legal conflict is one of the dimensions in agrarian conflict such as the struggle for and tenure of the land between the state and the people using legal instruments. Another hand, the state, in this case, the government apparatus from the central to local governments relies more on legalisticpositive state laws, while, local people on folk law or customary law that originate from the community and have existed communally for generations (Mustain, 2007).

The studies on agrarian conflicts have been conducted such as agrarian conflicts from the peasants reclaiming social movement perspectives (Mustain, 2005). Agrarian conflicts in the perspective of unequal relations between the state and local communities in forest resource management (Rosyadi \& Sobandi, 2014). The use and penetration of positive state laws against agrarian conflicts do not automatically resolve the problems in equitability for the local people (Ikhsan, 2013). In agrarian conflict, the presence of state laws and regulations does not present social order, merely creates complexity for the communities. The local people perceive formal- 


\section{A Relational Analysis of State Law and Folk Law in the Bongkoran Agrarian Conflicts, Banyuwangi Regency, East Java, Indonesia}

procedural affairs and mechanisms as "a burden", not only the relatively complicated requirements, mechanisms, or procedures, but also local structural realities with their simplicity are too "limited" to meet the demands of the formal affairs system (Warman, 2010).

In normative, the regulation of control, ownership, and utilization of agrarian resources, including land, has been regulated in the constitution, as in Article 33 Paragraph 3 of the 1945 Constitution of the Republic of Indonesia, "The land and the waters, as well as the natural riches therein, are to be controlled by the state to be exploited to the greatest benefit of the people" (Republik Indonesia, 2002). The article later produces the principle of the state's right to control, in which the state as an organization of power for all the people has the authority to regulate in a positive law, which is detailed in Law Number 5 of 1960 or better known as Basic Regulations on Agrarian Principles (Undang-Undang Pokok Agraria or UUPA). In Article 2, the principle of the state's right to control includes; (a) to regulate and implement the appropriation, the utilization, the reservation, and the cultivation of that earth, water, and air space as mention above; (b) to determine and regulate the legal relations between persons concerning the earth, water, and air space; and (c) to determine and regulate the legal relations between persons and legal acts concerning the earth, water, and air space. Although the authority originating from the state's right to control to regulate agrarian resources, including land, through state law, in Paragraph 3 explicitly states that the authority to regulate agrarian resources is used to achieve the greatest prosperity of the people in the sense of nationality, welfare, and independence in society, and an independent, sovereign, just, and prosperous Indonesian rule of law (Republik Indonesia, 1960).

Besides, the regulation of control, ownership, and use of agrarian resources, including land, is also based on local law, or in other terms as customary law or based on local wisdom. Historically, before The Unitary State of the Republic of Indonesia was established, even before the colonial period, some small communities based on bloodline and territorial ties later known as indigenous communities. The indigenous community entity has its indigenous knowledge in terms of agrarian resources issues, both in control, ownership, and utilization of agrarian resources and mechanisms for resolving conflicts and disputes (Koeswahyono, 2019). In short, UUPA enforces the dualism of law in regulating agrarian sources; they are state law and folk law. However, practically, state law is more dominant, eliminating folk law, and eliminating people's rights to their lands. Since this legal dualism, Koeswahyono (2019) explains that efforts to unify law (between state law and folk law in one positive state law) during the colonial period, even until now, have failed, due to state law was irrelevance with the awareness of folk law (volksgeist) or in Eurlich's thinking as living law or law that lives in the communities.

This research is about the Bongkoran land conflict case, in Wongsorejo Sub-district, Banyuwangi Regency, East Java Province, Indonesia. The conflict has a long history, that began in the 1950s and it continues until today with the inequitable resolution, even the conflict has increased. According to the Head of Wongsorejo Banyuwangi Farmers Organization (Yatno Subandio) said that currently 287 farmer families in Bongkoran village have lived and worked on 220 hectares of land since the 1950s. In 1988, the government unilaterally issued Cultivation Rights Title for kapok plantation to PT Wongsorejo with a land area of 606 hectares, including land claimed to be owned by the farmers in it. The Cultivation Rights Title permit expires in December 2012. The company intends to apply for a permit extension, but the people of Bongkoran refuse to extend the Cultivation Rights Title permit (Purbo et al., 2015).

On 18 September 2014, the National Land Agency of Banyuwangi Regency unilaterally issued new legality, in the form of Building Rights Title which was separated into two Building Rights Title certificates for PT Wongsorejo with a total area of 487 hectares. On the Building

Copyright (C 2020. Owned by Author(s), published by Society. This is an open-access article under the CC-BY-NC-SA license. https://doi.org/10.33019/society.v8i2.195

421 


\section{A Relational Analysis of State Law and Folk Law in the Bongkoran Agrarian Conflicts, Banyuwangi Regency, East Java, Indonesia}

Rights Title of the land, the Regional Government of Banyuwangi Regency plans to establish an industrial area called Banyuwangi Industrial Estate Wongsorejo (BIEW). The Building Rights Title permit and the Wongsorejo industrialization project were also rejected by the people of Bongkoran. As a solution, the local government and PT Wongsorejo offered 60 hectares of land to the farmers, but they rejected it since it was considered too small and insufficient for agricultural land and shelter. Besides, the Wongsorejo industrialization project is considered to be threatening and changing the culture of the population from farmers to industrial workers. Post land acquisition by PT Wongsorejo since the 1980s, the struggle, and resistance of the Bongkoran land farmers have been continuously conducted to obtain rights to their land, but until today it has not produced any results (Organisasi Petani Wongsorejo Banyuwangi, 2018).

After the Building Rights Title having issued for Banyuwangi Industrial Estate Wongsorejo (BIEW) project, agrarian conflicts were getting increased and marked by acts of violence. Acts of violence, intimidation, and criminalization to the people, and the farmers often occurred by government officials, security, and companies. Several Bongkoran farmers were shot and detained in one violent incident in 1999, 2001, and 2015. Until today, the conflict is still frequent, both latent and manifest. The most recent incident was on November 21, 2017, PT Wongsorejo will place building materials for the construction of the guard post on the disputed land however the local people oppose it. According to the people, the plan for placing building materials was located on people/farmers' land (Organisasi Petani Wongsorejo Banyuwangi, 2000; Lembaga Bantuan Hukum Surabaya, 2001).

The presence, intervention, and domination of state law often raise agrarian conflicts, instead of solving problems on a local base, but instead become new burdens and problems for local people. State law is more oriented towards formalism and proceduralism, while the people or farmers are more oriented towards the values, norms, and laws of their communities that have been the rules and customs by generations. The presence of state laws and regulations in the socio-cultural life of the community does not present social order but instead creates complexity for local people (Warman, 2010).

Empirically, the relationship between state law and folk law in Bongkoran agrarian conflicts is conflictual and unequal. Therefore, the focus of this research is to answer the following questions; firstly, how state law is implemented in agrarian conflicts in Bongkoran, Banyuwangi Regency. Secondly, how can state law subjugation folk law so that the folk law has been a weak bargaining position before state law? These issues are studied using the sociology of law approach.

Sociologically, the reality of Indonesian society is diverse in various ways, including the legal system. Every community has its customs and traditions by generations, has social norms, rules, and local procedures to regulate the community relations with agrarian sources, regulate social relations among the people in the community in control and use of land, including land division and conflicts, even they have institutions to solve various problems or better known as folk law. At the same time, the state seems to "impose" national laws to be enforced throughout society without differential treatment. According to Wignjosoebroto et al, (2011), sometimes the enforced national law does not accord with the norms of local communities. So, when that happens, the state law which is not following the "law" of the people tends not to be elected. The communities may against it.

The issue of agrarian conflict with legal dimensions needs a more comprehensive explanation and empirical analysis to provide a more sense of justice for local communities. In this context, the sociology of law approach is relevant to explain it. This approach can explain the socio-legal reality that occurs in the communities, especially concerning agrarian conflicts.

Copyright (C) 2020. Owned by Author(s), published by Society. This is an open-access article under the CC-BY-NC-SA license. 
So far, the juridical-normative approach is considered unable to provide a complete explanation since it is bound by rigid articles so that it is unable to reveal aspects of truth and legal justice for local communities.

\section{Research Methodology}

This research used a qualitative method with the legal sociology perspective and participative research methods. To obtain valid, factual, and empirical data, this research used the participatory method. This approach was to understand and analyze the implementations of laws that occur in agrarian conflicts, especially between state law and folk law in the agrarian conflict of Bongkoran, in Banyuwangi Regency. Qualitative research provided space and opportunities to describe and interpret data in more detail on the object under the research to get a more comprehensive understanding (Marvasti, 2004). The research subjects consisted of some elements including farmers/local people of Bongkoran, Community Legal Advisors, Government (Local Government, National Land Agency, and Police), and corporate elements (PT Wongsorejo). The nine informants had been selected by using purposive sampling technique with certain considerations that have been known beforehand, namely recognizing and understanding the problems under the research. The data were collected in February 2019 April 2019.

The main source of qualitative data was from words and explanations conveyed by informants that are directly related to the theme studied. Therefore, qualitative research used a natural setting, to interpret the phenomena occurred. Therefore, data collection was conducted using three integrative methods including observation, in-depth interviews, and document utilization (Moleong, 2012). Data collection was presented in the form of verbal words, not in the form of numbers (Muhajir, 1996). The analysis technique used was qualitative analysis techniques. The data were collected, selected, and analyzed qualitatively by referring to the framework that has been presented to provide a clear and comprehensive description of the problem under this research.

\section{Results and Discussion}

\subsection{Intervention and Dominance of State Law in the Agrarian Conflict of Bongkoran}

The legal issue in the agrarian conflict of Bongkoran, Banyuwangi Regency, has a long historical root. Historically, the people of Bongkoran village have a long history of controlling and utilizing Bongkoran land.

The elders of the local community said that the land of Bongkoran was inherited by the Dutch (in the form of the dense forest) that was neglected and then controlled and used by local people/farmers for generations (before independence until now) as agricultural land and became the name of the village "Bongkoran". This land is the source of life and livelihood for them. They had cleared the land and began planting before independence, in the 1942s. This land also included land with the status of erfpacht rights which was then controlled by the Dutch colonial. Post-independence, the land has been cultivated by Bongkoran farmers until these days (Organisasi Petani Wongsorejo Banyuwangi, 2000).

The Head of the Wongsorejo Banyuwangi Farmers Organization (Yatno Subandio), which has been a forum for agrarian justice struggles, explained that parents and elders in Bongkoran village often tell stories about the history of the disputed Bongkoran land now that the residents of Bongkoran village have cleared land since before independence in 1945. The land became a forest full of shrubs after being abandoned by the Dutch. Then, the local people cleared this land manually and used tractors for agricultural areas as their source of livelihood. Agricultural

Copyright (C 2020. Owned by Author(s), published by Society. This is an open-access article under the CC-BY-NC-SA license. 


\section{A Relational Analysis of State Law and Folk Law in the Bongkoran Agrarian Conflicts, Banyuwangi Regency, East Java, Indonesia}

land produces agricultural products such as corn, chilies, sweet potatoes, vegetables, and so on. Apart from their consumption, some are sold in the local market. According to the local community, the land of Bongkoran has previously controlled and utilized the people/farmers of Bongkoran compared to PT Wongsorejo, which arrived in 1988 with the legality of the Cultivation Rights Title permit. According to local people, the legality of the Cultivation Rights Title permit was issued unilaterally and the community did not know the ownership of PT Wongsorejo. In other words, this socio-historical fact cannot be ignored in the conflict and the resolution of agrarian conflicts in Bongkoran.

Meanwhile, the government relies more on state law or formal legal aspects. The Head of Wongsorejo sub-district, Sulistyawati, said that the Bongkoran land conflict can be resolved if one of the disputing parties has formal legal evidence. PT Wongsorejo can provide legal evidence of land ownership and control in the form of Cultivation Rights Title and Building Rights Title permits. Meanwhile, the local community does not have one. Thus, legally, PT Wongsorejo has the right to own the land. The National Land Agency of Banyuwangi Regency also sides with the legality aspect of the disputed land status. The National Land Agency of Banyuwangi Regency adheres to the legal-formal aspects of the company. The company can show its formal legal status, such as the Cultivation Rights Title and Building Rights Title permits, while the people of Bongkoran are deemed to have no legality in the land they control. The National Land Agency of Banyuwangi Regency official, Mujiono, said that when people/farmers of Bongkoran came to the National Land Agency of East Java Province, they could not show formal evidence and legality of the land.

The agrarian conflict of Bongkoran got more intense when in 2014; the local government of Banyuwangi Regency issued Regional Regulation Number 8 of 2012 concerning the 2012-2032 Banyuwangi Regency Spatial Plan (Kabupaten Banyuwangi, 2012), which includes legalizing Banyuwangi Industrial Estate Wongsorejo (BIEW) development project plan by PT Wongsorejo. This regional regulation makes PT Wongsorejo proposed a transfer of land concession permits in the Wongsorejo area from Cultivation Rights Title to Building Rights Title. Even though the Bongkoran land is still in dispute with the local people, the National Land Agency is still adamant about issuing legality (Building Rights Title) for the Wongsorejo industrialization project. The government (the National Land Agency) is more siding with and serving the interests of the owners of capital, rather than fairly resolving conflicts. According to the National Land Agency of Banyuwang Regency official, Mujiono, the current status of Bongkoran land, which controlled by PT Wongsorejo has changed, from Cultivation Rights Title to Building Rights Title for 30 years (since 2014). This land will be an industry or factory for business purposes. This industrial area already has legality, such as a regional regulation that regulates the industrialization area; one of them is the Wongsorejo area.

In this agrarian conflict, the National Land Agency is in line with the opinion of the police, which states that as long as the member of the Farmers Organization and community of Bongkoran can show legal evidence, the National Land Agency will process the legality of the claimed land. But if they cannot show evidence, the National Land Agency of Banyuwangi Regency will allow it to be resolved through legal or court channels. According to the National Land Agency of Banyuwangi Regency official (Ibnu Faizin), the history of the Wongsorejo juridically is clear, starting from the erfpacht land in the Dutch era continued to be given to the kapok plantation company, PT Wongsorejo through Cultivation Rights Title, then permits extended, and now changed to Building Rights Title for the benefit of industrialized areas based on a decision by the regional government (Regent and Regional People's Representative Assembly) through Regional Regulation.

Copyright (C) 2020. Owned by Author(s), published by Society. This is an open-access article under the CC-BY-NC-SA license. 


\section{A Relational Analysis of State Law and Folk Law in the Bongkoran Agrarian Conflicts, Banyuwangi Regency, East Java, Indonesia}

Through Regional Regulation Number 8 of 2012 concerning the 2012-2032 Banyuwangi Regency Spatial Plan; a land area of 600 hectares in Wongsorejo Village, Wongsorejo Subdistrict has been prepared to establish an industrial area. The land for the industrial estate uses kapok plantation land controlled by PT Wongsorejo through Cultivation Rights Title. Currently, the Cultivation Rights Title has turned into a Building Rights Title permit with a land area based on the Building Rights Title certificate covering an area of 487 hectares and is legally owned by PT Wongsorejo. According to the Development Planning Agency at Sub-National Level of Banyuwangi Regency official (Edi Purnomo) said that 2,000 hectares of land in Wongsorejo, including PT Wongsorejo's land, has been designated as industrial areas by regional regulation. Thus, the government issued a Building Rights Title permit to PT Wongsorejo, which plans to build an industrial area. Legally, the land area of 487 hectares has been the authority of PT Wongsorejo as the holder of the land rights as stated in the Building Rights Title permit.

The basis for formal legality is always used and becomes the benchmark for local government officials in granting permits to continue the Banyuwangi Industrial Estate Wongsorejo (BIEW) project from PT Wongsorejo. The basis and legal instruments are also used by the local government to pressure the people of Bongkoran. A formal legal basis is also used by the police in this agrarian conflict. According to the Head of Operation Subdivision of Banyuwangi Police Office (Iptu Hadi Waluyo) said that police are based on the rules. As a law enforcer, the guidelines are the law. Local governments are also based on the rules of the game and positive law (legal formal).

Meanwhile, PT Wongsorejo followed the mindset of the government and the National Land Agency, which claimed that land controlled by the company was legal and obtained through legal channels and procedures. According to Corporate Communication of PT Wongsorejo (Tria Utama), said that PT Wongsorejo has Building Rights Title which is protected by law. Furthermore, Tria Utama said that PT Wongsorejo agrees that this issue must be placed in a legal context. PT Wongsorejo already controlled this land through legal channels, which was obtained with Building Rights Title in 1988. PT Wongsorejo previously bought this land with Building Rights Title status from the previous owner (Budi Sanjaya). So legally, this land status is already clear owned by PT Wongsorejo. If indeed they (the local community) claim a land area of 220 hectares, they should file it with the court and resolve the problem through legal channels.

Explanations submitted from the state or government through Local Government, Police, and the National Land Agency, as well as corporation (PT Wongsorejo) tends to ignore empirical, sociological, and historical facts about the existence of land rights in Bongkoran. Juristically, agrarian law politics refers to the main organic laws concerning agrarian, Law Number 5 of 1960, better known as Basic Regulations on Agrarian Principles (Undang-Undang Pokok Agraria or UUPA). Although this law recognizes the existence and sovereignty of customary law communities and customary lands or local community lands, there are other regulations (for example, Law Number 41 of 2009) that negate this principle and then remove people/customary lands. In the name and legal authority of the state, people's land rights are increasingly being eliminated. This legal conflict then led to an unsolved agrarian conflict.

Although still in conflict status, with the permit of Building Rights Title, PT Wongsorejo has started the Wongsorejo Industrialization area project in 2018, and according to Tria Utama's statement, this project in 2019 is expected to require about 70,000 workers with the priority of local people. Amid the conflict, the company tried to persuade the people of Bongkoran to accept the Wongsorejo industrialization area project with a guarantee that the people of

Copyright (C) 2020. Owned by Author(s), published by Society. This is an open-access article under the CC-BY-NC-SA license. 


\section{A Relational Analysis of State Law and Folk Law in the Bongkoran Agrarian Conflicts, Banyuwangi Regency, East Java, Indonesia}

Bongkoran would become their workers. Consequently, there will be land-use change; from agricultural land to industrial land. The farmers of Bongkoran, who have been dependent on land and their strong socio-historical ties, are threatened with breaking up and being replaced by industrial workers. For the company, it opens up opportunities for Bongkoran farmers to work in the industrial sector as a solution to ending disputes that occur. For the company, the solution is under the regional regulation which stipulates the disputed area as a nonagricultural industrial area, so that people of Bongkoran have to switch to sectors that support industry.

Based on Regional Regulation Number 8 of 2012 concerning the 2012-2032 Banyuwangi Regency Spatial Plan, Wongsorejo Sub-district will become an industrial area consisting of the base metal industry, basic chemical industry, petroleum industry, machinery and equipment industry, wood, rubber, plastics, paper, food, and beverage industry. The legalization of this industrialization project has put more pressure on the existence of the Bongkoran people. Life and source of life as a farmer will be lost. Because of this, the people/farmers of Bongkoran firmly reject the industrialization policies and projects of the Wongsorejo area. For the people of Bongkoran, The Banyuwangi Regency Government policy through Regional Regulation Number 8 of 2012 further exacerbated agrarian conflicts in Bongkoran. The Banyuwangi Regency Government and the National Land Agency act more and serve the needs and interests of the company than to resolve agrarian conflicts with the community.

Basic Regulations on Agrarian Principles recognizes the rights of customary communities to control land and natural resources. However, many other sectoral regulations (natural resources) negate this principle (for example, one of which is Law Number 41 of 1999) which recognizes the existence of customary forests or folk law that exists and becomes a reference in the control and use of land. However, this law places customary forests as part of state forests with the principle of the state's right to control. In this case, the state had the sole authority and ignores folk law and land rights of people (Republik Indonesia, 1999). The conflicts between the two legal systems often lead to prolonged horizontal and vertical conflicts. This condition illustrates that there is a gap between lawmakers (state institutions) and the community. This condition makes state law dysfunctional in its implementation (Wahyuni, 2016).

From the above explanation, it illustrates that legal conflicts in agrarian conflicts, including in Bongkoran, Banyuwangi Regency, have historical roots and contain the practice of land grabbing using legal instruments that continue developed until today. The implementation of state law in agrarian conflicts in Bongkoran has a more dominant and hegemonic character. For the government apparatus, there is only one national law that applies in all Indonesian territories in regulating the control, ownership, and utilization of agrarian resources (land), namely the state law which is more certain. Meanwhile, local law or folk law is considered to be uncertain and disturbs the existence of state law and state interests, including corporate interests. Therefore, in the interests of the state and corporations, state law is often implemented repressively.

In the view of the people/farmers of Bongkoran, the land controlled by the government and corporations is the spoils of the community that have occurred since the Dutch colonial era until today. Historically, related to the practice of confiscating people's land through legal instruments, in the Dutch colonial era, the practice of land grabbing was conducted through the Agrarian Law (Agrarische Wet 1870), and continued after independence, when the government nationalized Dutch plantation companies in 1957-1958. The state through its military instruments forcibly took the peasants' lands. Therefore, it is very natural for local people to fight back or according to Boedhi \& Perdana (2001) as a reclaiming movement, namely the

Copyright (C) 2020. Owned by Author(s), published by Society. This is an open-access article under the CC-BY-NC-SA license. https://doi.org/10.33019/society.v8i2.195

426 


\section{A Relational Analysis of State Law and Folk Law in the Bongkoran Agrarian Conflicts, Banyuwangi Regency, East Java, Indonesia}

social movement of the community in taking over natural resources, including land that was previously grabbed by the state. The "legal" grabbing of people's land continued in the New Order era with increasingly repressive actions. In development efforts (economic), the government in the New Order era took people's lands and then gave them to the private sector through the plantation permits (Cultivation Rights Title and Building Rights Title), forestry permits, mining permits, and other contracts of work permits. During this time, the military grabbed land belonging to the tenant peasants who were accused of being involved in the Communist Party of Indonesia and then took over by the state and became state land. Land grabbing continued in the Reform era. Several New Order laws and regulations which were later updated in the Reform era, also made it easier to land grabbing. The ideology of growth developed by the New Order continued in the form of a long-term economic development program known as the "Master Plan for Acceleration and Expansion of Indonesia's Economic Development" which presupposes global land grabbing. Land grabbing is not only local or national but is related to global land grabbing (Herwati as cited in Pujiriyani et al., 2014).

Regarding legal conflicts in agrarian conflicts, Rachman (2016) stated that the source of agrarian conflicts comes from claims of rights to land and/or other natural assets originating from different reasons, which are believed by each party (the state and local communities). Each party has a claim of legal validity to control and maintain the functions of the area and its resources. These differences of course contain dimensions of importance that are different from one another. Meanwhile, Mustain (2007) stated that law, both in nature and the background in which it was formed, generally does not reflect folk law that lives and is followed by local communities. The validity of state law formation and implementation stems from the state's authority, and power. Meanwhile, folk law is generally local, non-formal, and has its strength in its reality as a pattern of behavior that is passed down from generation to generation.

Empirically, the legal conflict between state law and folk law in the agrarian conflict of Bongkoran is not sufficient to be handled with a state law approach alone, but it is necessary to consider a sociological legal approach, an approach based on the socio-historical aspects of the community. An Austrian legal sociologist, Eugen Ehrlich (1862-1922) stated that good law is the law of living in a society or what is called Living Law. Law was born out of the womb of the public, develops, and lives for the public. The law in a country or society is the law under the values that develop and live in society. This is in line with the historical law, Von Savigny (1779-1816) stated that the law will depend on and follow the history of the development of its society. Law is a reflection of the soul of the nation or society (volkgeist). Therefore, when the law becomes a reflection of society, it is not easy to force people to punish according to rigid methods as in positive state law, which is not rooted in values and habits or socio-cultural conditions in society (Rahardjo, 2009).

Therefore, from the perspective of legal sociology, the law has many dimensions, including the agrarian conflict in Bongkoran. The resolution of agrarian conflicts through legalistic positivistic state law instruments often creates legal injustice for local community groups. Agrarian conflicts are not sufficiently resolved by using a legalistic-positivistic approach to state law but need to be complemented by a sociological legal approach. In a sense, agrarian conflicts must also be placed in a holistic social, cultural, economic, and political context of agrarian law. Empirically, agrarian conflicts are part of legal and social problems that are very complex and cannot be answered in a normative way. The approach of social science, legal anthropology, or legal sociology is very helpful in being able to explain how the law works and operates in people's daily lives (Irianto, 2011). Therefore, the resolution of agrarian conflicts in Bongkoran requires the operation of laws that are more just for local communities. Law does not just work

Copyright (C) 2020. Owned by Author(s), published by Society. This is an open-access article under the CC-BY-NC-SA license. https://doi.org/10.33019/society.v8i2.195 
based on rigid articles in the law, but must pay attention to the socio-cultural and historical context of the community. According to Wignjosoebroto (2010), just law is a national law which in its application from case to case can greet the moral principles that apply in local communities whose truth is still believed by the local community.

As the author of the book in 1919 "De Indonesiër en Zijn Grond", Cornelis van Vollenhoven, which is translated into Indonesian with the title "Orang Indonesia dan Tanahnya" (Indonesian People and Their Land), at least proposes three important ideas on the importance of an empirical or sociological legal approach to understanding more about the laws that live in society. First, legal studies using social sciences by going directly to the local field (life in society) will be able to describe, analyze, and systematize field findings as accurately as possible. The sociology of law will be able to reveal living laws, which the state must pay attention to. Second, legislators or state lawmakers and their bureaucratic institutions are often referred to as office masters or authorities who often make wrong, unfair, and inconsistent laws. Third, the issue of law enforcement at different levels. In this context, a state law that has national legitimacy should not "arbitrarily" suppress the existence of community law or customary law. On the other hand, state law not only recognizes the existence of folk law or customary law but also accommodates laws that live and are still being used by local communities (Safitri \& Moeliono, 2010).

\subsection{The Domination Patterns of State law on Folk Law in Agrarian Conflict of Bongkoran}

In the conflict, the domination of the state law on folk law raising a strong reaction from the local community. The dominance of the state law has addressed injustice for them since it neglects the socio-historical conditions of local people. The government has carried various ways out; both local government and local security forces along with PT Wongsorejo to dominate the local communities, both in persuasive and repressive ways, with the main objective of realizing the interests of controlling agrarian resources (Afrizal, 2018). In 2014, the conflict escalated after the Building Rights Title permit for PT Wongsorejo was issued. This condition drove the Regional Leadership Communication Forum that consisting of the Regional Government, Police, and the National Land Agency to mediate by presenting PT Wongsorejo and the local people (farmers' organization). As a result, the company will give 60 hectares of land to the local people, but the local people refused and kept claiming for 220 hectares of land. Apart from the rejection of the offer, the community has also rejected the Woangsorejo industrial area project which is considered as more harm to the farmers of Bongkoran.

Regional governments have implemented persuasive methods. For instance, at the beginning of the New Order, to control land in the Wongsorejo area, the local government offered farmers and the people in Bongkoran village controlled and used the land as agricultural land. If they wanted more land, they could join the transmigration program to Kalimantan and Sumatra. Not only persuasive methods, but also specific methods, namely if the community refused or were difficult to regulate, the community would be labeled as the Communist Party of Indonesia's henchmen, and this applies to all smallholders in Wongsorejo village (Purbo et al., 2015).

PT Wongsorejo also implemented a persuasive way to influence the people/farmers of Bongkoran to release their lands as an Industrial Area by offering and promising jobs with the lure of better wages for the local people of Wongsorejo. According to the Corporate Communication of PT Wongsorejo (Tria Utama), said that if the Wongsorejo industrial project is built, the company will promise jobs to them. Wongsorejo residents, their families, and relatives can become industrial workers with a decent salary to support their children and families.

Copyright (C 2020. Owned by Author(s), published by Society. This is an open-access article under the CC-BY-NC-SA license. https://doi.org/10.33019/society.v8i2.195

428 


\section{A Relational Analysis of State Law and Folk Law in the Bongkoran Agrarian Conflicts, Banyuwangi Regency, East Java, Indonesia}

Furthermore, Tria Utama said, that students who have graduated from high school can work in the Wongsorejo industrial area. The company will recruit around 70,000 new workers and most of them can be drawn from the people of Wongsorejo. However, the lure of jobs and salaries did not reduce the people and farmers rejected the Wongsorejo industrialization project.

Meanwhile, the security apparatus, especially the police, have also taken a persuasive approach with a legal approach and support for the company which gave 60 hectares of land to the people of Bongkoran. The police still adhere to the applicable laws. People of Bongkoran are asked to obey the state law. This is as explained by the Head of Operation Subdivision of Banyuwangi Police Office (Iptu Hadi Waluyo), said that police are based on the rules. As a law enforcer, the guidelines are the law. If they want to find a solution, the people of Bongkoran must accept offering 60 hectares. The land can be used for agriculture. In terms of ownership, PT Wongsorejo already has legal ownership.

Meanwhile, repressive methods were also conducted, including local government officials, security forces (Indonesian National Army/Indonesian Republic Police), and company foremen. If traced back, the approaches and methods of violence have been repeatedly conducted by local government officials, security forces (Indonesian National Army/Indonesian Republic Police), in the form of symbolic, psychological, and physical violence. Symbolic, for example, is labeled as the Communist Party of Indonesia's henchmen to members of the community who refuse to be transmigrated outside Java Island. Psychic intimidation, for example, by deploying the Indonesian National Army/Indonesian Republic Police officers to guard the area or land and frightening the local people who remain on the disputed land. In the records of the Wongsorejo Banyuwangi Farmers Organization, it was stated that in 1999-2000, when the Reformation era started, there was intimidation against local people, physical violence, criminalization of local people/farmers, and also the arrest, detention, and shooting of local people. Meanwhile, in 2014 when the National Land Agency issued the Building Rights Title for PT Wongsorejo, there was a clash when local people/farmers tried to block a company-owned bulldozer which was guarded by Indonesian National Army/Indonesian Republic Police officers destroying farmers' land with the excuse of building roads. Approaches and methods of violence are carried out by state apparatus and companies to suppress and expel people from the land that has been the place of people/farmers and source of livelihood for local communities. The security approach and the use of legalistic-positivistic state legal instruments do not resolve conflicts, but instead, exacerbate conflicts and protracted conflicts.

The existence of acts of violence from the security forces was also conveyed by the Legal Advisor of the people/farmers of Bongkoran (Abdul Fatah), from Surabaya Legal Aid Agency. According to Abdul Fatah, Surabaya Legal Aid Agency while assisting cases of agrarian conflict and legal cases experienced by Bongkoran people have long received unfair and violent social and legal treatment. Violence perpetrated by corporations against people/farmers of Bongkoran has never been enforced by law enforcement institutions. There are legal imbalances and injustices. The violence reported by the people/farmers was never followed up.

The patterns of domination that carried out by the government along with the company through violence cannot be separated from the interests of controlling people's lands for the capitalists. The state with its powers, including using legal instruments to seize people's land rights and transfer land tenure rights to other parties, in this case, the business actor, PT Wongsorejo, through the granting of concession permits, both in the form of Cultivation Rights Title and Building Rights Title. The process of transferring access and control over land from local people to other parties, especially to business actors, is met by various methods used by

Copyright (C) 2020. Owned by Author(s), published by Society. This is an open-access article under the CC-BY-NC-SA license. 


\section{A Relational Analysis of State Law and Folk Law in the Bongkoran Agrarian Conflicts, Banyuwangi Regency, East Java, Indonesia}

political authoritative institutions, such as the use of bureaucratic instruments and government regulations, as well as direct or indirect manipulation, intimidation, and violence (Perdana et al., 2014).

Historically, the practice of grabbing people's land using state-legal instruments has been going on since before independence. In the Dutch colonial era, the confiscation of people's land was carried out using colonial Agrarian Law (Agrarische Wet 1870) with the principle of domein verklaring which was very detrimental to the community, namely the concept of political law which was very hegemonic and became an instrument to take over people's lands in Java Island. This law was used by the colonial government to facilitate private companies (European capitalists) through the rights of erfpacht for 75 years. Basic Regulations on Agrarian Principles tried to erase the nature and practices of colonialism and land exploitation that was detrimental to the community and was replaced by the political principle of the state's right to control. The power and regulatory authority of natural resources, including agrarian affairs, are controlled and regulated by the state unilaterally (Rachman, 2016; Boedhi \& Perdana, 2001).

Violence seems to be still an important instrument used by the government and corporations in subduing local communities in agrarian conflicts. Although the New Order's repressive regime has passed and replaced with the Reformation Order, this does not mean that the approaches and means of violence in dealing with agrarian conflicts have stopped. The approach and methods of violence using military force from the Indonesian National Army/Indonesian Republic Police still occur, including in the agrarian conflict of Bongkoran. These violent methods have to be carried out, not only because of the interests of state law but also because of economic interests and corporate business. This approach and methods, according to Himan (2005) as cited by Rachman (2016) as a whole series of violence can be understood as part of primitive accumulation, the initial process of returning capitalism to work in Indonesia. This fact also shows how state law is used by government and security officials as well as companies to pressure and get rid of farmers for the company's business interests. In industrial society, laws are made by the state to serve the business interests of the owners of capital. In Marx's view, the state always sided with the ruling social class and oppressed the lower class or the weaker society. The state is considered an institution that has legal and moral legitimacy to do anything, to guarantee and protect the interests of its power, including the business interests of investors (Magnis-Suseno, 2001).

As a formal political institution, in the New Order era, the state had the sole authority in making and determining its laws, but in the era of reform and democracy and along with strong economic interests supported by corporate activities (both national and global), laws produced by the state could always tie up to the business interests of the capitalists. State law is used to serve the business interests of the capital owner. So it is natural that there is collaboration between the state and corporations in exploiting natural resources and agrarian sources (land) through the legal products they make. State power is no longer the party that has the sole power in agrarian conflicts and natural resource management. In this context, agrarian conflicts are getting tougher, when there are major forces to collaborate and unite namely the state and corporations to suppress communities using legal instruments. Bargaining the corporate position is getting stronger and can be equal to the state. The state as a political institution, the main regulator of people's lives, is experiencing a decline in line with the strong influence of corporations with expanding business interests.

The state is not increasingly autonomous, including in the formation of laws that depend more on the will and interests of the economy or corporations. Laws made by the state can be said to be a product and a reflection of corporate interests. Therefore, in the view of the

Copyright (C 2020. Owned by Author(s), published by Society. This is an open-access article under the CC-BY-NC-SA license. 


\section{A Relational Analysis of State Law and Folk Law in the Bongkoran Agrarian Conflicts,}

Banyuwangi Regency, East Java, Indonesia

Marxists, state law is made only to serve the interests of the capitalists rather than the interests of society at large. In other words, the existence and position of society in such a relationship, is getting worse and will continue to be victims of injustice from an unequal relationship.

The strong hegemony of state law has increasingly pressed folk law. Adopting the concept of Gramsci, the hegemony of state law can be carried out through violent means or consensus. Through consensus, state law hegemony over society is built through a relationship of agreement using political and ideological leadership (Simon, 2004). Development through industrialization with state legal instruments is believed to provide public welfare. Meanwhile, local people are against the discourse of self-developed welfare. Development and industrialization policies designed by the state and given to the private sector are always claimed to be an effort to improve the welfare of citizens. However, for the community, industrialization by grabbing community land rights has damaged the socio-economic and cultural fabric of local communities. Not welfare, but structural poverty for local communities (farmers). Local people are cut off from their source of life, namely the land.

Development (Wongsorejo industrialization area) does not create welfare for local communities, but elite groups, including business people. In the context of the struggle to build hegemony, industrialization-based development is the meaning and narrative that the state is trying to build as hegemony. The state wants to build hegemony of development based on industrialization and land as its material basis, and local communities (farmers) are building counter-hegemony over the hegemony of the state (Ardianto, 2016). Strengthening the awareness of local communities to implement folk laws, and ignoring state law is not only because they consider state law in its implementation to be full of violence and injustice, but also as a form of counter-hegemony carried out by local people (farmers) against state law.

Sociologically, local people feel they have land rights based on socio-historical legality. Control, ownership, and utilization of land are obtained through a long historical and social process (hereditary). The peasants' movement that carried out the reclaiming movement that occurred in various areas of agrarian conflict, including in Bongkoran, was an expression of fighting the agrarian injustice committed by the state by force-grabbing land, especially during the New Order era. The loss of land for the farming community is the loss of life. Land for farming communities is the heart of life.

The land is an inseparable part of the socio-economic life of local communities. The land is a support for the socio-economic and cultural life of the local community. Land does not only have an economic function (source of livelihood) but has a social and cultural function. All social and cultural activities of the local community need land as a unifier. Although they do not have formal legality of ownership and control of land, the community has a long history with the land before positive laws and the state existed.

In the study of agrarian conflicts, Afrizal (2006) stated that the state is an important factor in causing agrarian conflict, while the solution to the conflict also depends on it. The resolution of agrarian conflicts must be returned to the state because the root of the problem stems from state action. The state is required to make a policy that can resolve the agrarian conflict. One solution is to make fundamental changes, by designing a political agrarian law that is more accommodating to the interests of the community who are disadvantaged by the forced takeover of people's lands by the state or companies.

According to Perdana et al, (2014), the unequal relationship between state law and folk law, including in agrarian conflicts, can at least be seen from three aspects. First, at an empirical level, folk law is often so easily weakened, eliminated, and even destroyed to give way to the political and economic power given way by the state's formal legal system. Unwritten folk laws

Copyright (C 2020. Owned by Author(s), published by Society. This is an open-access article under the CC-BY-NC-SA license. https://doi.org/10.33019/society.v8i2.195

431 
are considered uncertain; do not support "modernization" so that they can hinder development. The destruction of folk law occurs so easily when the local socio-political structure is subjugation and subordinated by a formal structure called the state (state law).

Second, the weakening, elimination, and destruction of the folk law have the consequence of the emergence of various forms and situations of the destruction of agrarian resources, sociocultural life, and the values and moral standards of local communities. The cases of eviction of customary territories, and seizure of people's land rights, using legal-formal instruments (state law), as well as instruments of state violence (Indonesian National Army/Indonesian Republic Police), are clear evidence that is still ongoing.

Third, understanding the situation that the development of the law and law developed, especially by the legal education system in Indonesia, emphasizes or focuses more on studies of state law with a legal-formal system, the method of law only relies on the articles in the "articleistic" of law. The rigid and articleistic law provides room for the exclusion of human rights, exploitation, environmental destruction, and the socio-cultural system of local communities.

The process of communication and legal relations in society often creates a different understanding between individuals, society, and the state. The state interprets the law with its logic (deductive logic), based on formal rules. Meanwhile, society interprets with inductive logic (empirical facts). In this context, Sampford (1989) show a relationship between law, individuals, and society, including the state which has full authority. On one hand, the state relies more on written, formal, legalistic-positivistic rules. Meanwhile, on the other hand, individuals and community groups outside the state rely on unwritten rules, are informal, based on values and norms that have been established by the community, or by the laws of the community itself.

Laws create and achieved by society are the product of several relations between social classes in society. As Marxists said, the law is a product and a reflection of capitalist society. Law was created to serve the interests of investors. The unequal social relations in a capitalist industrial society are between the bourgeoisie and the proletariat. Nothing in history has political institutions and organizations been arranged so systematically and rationally with such great power as the modern state. The modern state exploits the original powers that were previously present in the territory and make the state the only power in the territory. There can be no counter-power. The state becomes an all-encompassing power organization and is fully sovereign in one area (Susanto, 2010).

In various social conflicts, including agrarian conflicts, the state using its authority as a rule of law (rechstaat) often forces the settlement of agrarian conflicts by using state law and overriding folk laws. Historically, the experience in the United States of America in the 1960s with industrialization and modernization, the use of state law with legalistic-positivistic characteristics, was unable to solve social problems, including social conflicts. As a legal entity, the existence of these two legal systems, the state law and people/customary law, cannot just be eliminated from people's lives, especially in the matter of agrarian conflicts. The two of them cannot negate each other. Juridically and socio-historically both exist and apply in society to this day.

Therefore, to reduce tensions and conflicts between state law and folk law in agrarian conflicts, there needs to be a new approach and understanding of the relationship between the two. A state with a legal formal system needs to understand that there are internal weaknesses in the legal system of the state and at the same time it is necessary to respect and protect the existence of folk law which is an inherent part of the life of local communities, including those

Copyright (C 2020. Owned by Author(s), published by Society. This is an open-access article under the CC-BY-NC-SA license. https://doi.org/10.33019/society.v8i2.195

432 


\section{A Relational Analysis of State Law and Folk Law in the Bongkoran Agrarian Conflicts, Banyuwangi Regency, East Java, Indonesia}

related to regulating land tenure and utilization. The existence and legal needs of the people/customary, according to Sumardjono (2018), are still needed in resolving agrarian conflicts. Customary/folk law is needed to complement norms that have not been regulated in state law, but which are needed by the community and perceived as something that exists, and thus fulfill the community's needs. The existence and enforcement of folk/customary laws must be understood as complementary elements. Besides, the existence and enforcement of folk law in the management of agrarian resources have a strong socio-historical basis and cannot be dismissed. State law needs to accommodate other laws that are alive, growing, and are still being used by local communities.

\section{Conclusion}

Agrarian conflict as a social reality that is a social disorder and is in an asymmetrical legal relationship, is not sufficiently intervened by using a legalistic-positivistic approach to state law that is far from a sense of community justice. A non-systematic and sociological legal approach is needed to provide a more sense of justice (agrarian) to the local communities. Justice does not only rely on state law which is legal-formal but can also rely on people's/customary law, which is informal. Communal local communities are more bound by folk law; this can be one way to get justice. Folk law has become an inherent part of the life of local communities which is full of the spirit of togetherness. In its implementation, folk law is more oriented to the principles of justice and benefit.

Legal relations in the agrarian conflict of Bongkoran, which are asymmetrical, have resulted in the strong domination and hegemony of state law over folk law and have resulted in patterns of subduing the state apparatus by using legal instruments, both persuasively and repressively. However, the state's pressure with its laws did not dampen the resistance of the Bongkoran farmers in fighting for agrarian justice.

The asymmetrical relation between state law and folk law has given rise to tensions and prolonged agrarian conflicts. Therefore, to reduce this tension, there needs to be a new understanding of the relationship between the two laws. It is time for the state and its legal system to not only recognizes the existence and validity of people/ customary laws juridically but also sociologically. The state and its legal system need to be aware and understand that there are internal weaknesses in the state legal system related to agrarian regulation, and at the same time it is necessary to respect and protect the existence and enforceability of folk law which have become an inherent part of the life of local communities. The existence and enforceability of people/customary laws must be viewed as complementary elements. The existence and enforcement of folk law in the management of agrarian resources have a strong socio-historical basis and cannot be dismissed. Therefore, state law needs to accommodate folk law; which is alive, grow, and is still being used by the local community communally and from generation to generation to this day.

\section{Acknowledgment}

The authors would like to express their gratitude to all informants, the Head of Wongsorejo Banyuwangi Farmers Organization (Yatno Subandio), the farmers, people of Bongkoran village, Surabaya Legal Aid Agency; Banyuwangi Police officials; the Development Planning Agency at Sub-National Level of Banyuwangi Regency officials, the National Land Agency of Banyuwangi Regency officials, and high officials of PT Wongsorejo.

Copyright (C) 2020. Owned by Author(s), published by Society. This is an open-access article under the CC-BY-NC-SA license. 
A Relational Analysis of State Law and Folk Law in the Bongkoran Agrarian Conflicts, Banyuwangi Regency, East Java, Indonesia

\section{Declaration of Conflicting Interests}

The authors have declared no potential conflicts of interest concerning the research, authorship, and/or publication of this article.

\section{References}

Afrizal. (2006). Sosiologi Konflik Agraria: Protes-Protes Agraria dalam Masyarakat Indonesia Kontemporer. Padang, Indonesia: Andalas University Press.

Afrizal. (2018). Sosiologi Konflik: Pola, Penyebab, dan Mitigasi Konflik Agraria Struktural di Indonesia. Sidoarjo, Indonesia: Indomedia Pustaka.

Ardianto, H. T. (2016). Mitos Tambang untuk Kesejahteraan: Pertarungan Wacana Kesejahteraan dalam Kebijakan Pertambangan. Yogyakarta, Indonesia: Penerbit PolGov.

Boedhi, W., \& Perdana, H. (2001). Reklaiming E Kedaulatan Rakyat. Jakarta, Indonesia: Yayasan Lembaga Bantuan Hukum Indonesia and RACA Institute.

Ikhsan, E. (2013). Konflik Tanah Ulayat di Tanah Komunal Etnik Melayu Deli Sumatera Utara (Master's dissertation). Medan, Indonesia: Universitas Sumatera Utara.

Irianto, S. (Ed.). (2011). Hukum Yang Bergerak: Tinjauan Antropologi Hukum. Jakarta, Indonesia: Yayasan Pustaka Obor Indonesia.

Kabupaten Banyuwangi. (2012, August 27). Peraturan Daerah Kabupaten Banyuwangi Nomor 08 Tahun 2012 Tentang Rencana Tata Ruang Wilayah Kabupaten Banyuwangi Tahun 2012-2032. Lembaran Daerah Kabupaten Banyuwangi Tahun 2012 Nomor 9/E. Retrieved from http://ditjenpp.kemenkumham.go.id/files/ld/2012/KabupatenBanyuwangi-20128.pdf

Koeswahyono, I. (2019). Tanah untuk keadilan sosial: perbandingan penataan dan pengaturan pertanahan di beberapa negara. Arena Hukum, 12(1), 64-90. https:/ / doi.org/10.21776/ub.arenahukum.2019.01201.4

Lembaga Bantuan Hukum Surabaya. (2001). Laporan Investigasi Kekerasan Aparat Kepolisian terhadap Petani Wongsorejo, Banyuwangi. Surabaya, Indonesia: Author.

Magnis-Suseno, F. (2001). Pemikiran Karl Marx: Dari Sosialisme Utopis ke Perselisihan Revisionisme. Jakarta, Indonesia: PT Gramedia Pustaka Utama.

Marvasti, A. B. (2004). Qualitative Research in Sociology. Thousand Oaks, Canada: SAGE Publications.

Moleong, L. J. (2012). Metodologi Penelitian Kualitatif (10th ed.). Bandung, Indonesia: PT Remaja Rosdakarya.

Muhajir, N. (1996). Metodologi Penelitian Kualitatif(3rd ed.). Yogyakarta, Indonesia: Rake Sarasin. Mustain. (2005). Gerakan Petani di Pedesaan Jawa Timur pada Era Reformasi: Studi Kasus Gerakan Reklaiming oleh Petani atas Tanah yang Dikuasai PTPN XII Kalibakar, Malang Selatan (Dissertation). Universitas Airlangga. $\quad$ Retrieved from http:/ / repository.unair.ac.id/32567/

Mustain. (2007). Petani vs Negara: Gerakan Sosial Petani Melawan Hegemoni Negara. Yogyakarta, Indonesia: Ar-Ruzz Media Group.

Organisasi Petani Wongsorejo Banyuwangi. (2000). Kronologi Konflik Tanah Bongkoran Wongsorejo Kabupaten Banyuwangi. Banyuwangi, Indonesia: Author.

Organisasi Petani Wongsorejo Banyuwangi. (2018). Kronologis Perjuangan Petani Wongsorejo Banyuwangi. Banyuwangi, Indonesia: Author.

Perdana, W. H., Arizona, Y., Putro, W., \& Simarmata, R. (2014). Hukum Rakyat: Tinjauan Konsep, Teori dan Filsafat. Jakarta, Indonesia: HuMa.

Copyright (C 2020. Owned by Author(s), published by Society. This is an open-access article under the CC-BY-NC-SA license. 
Pujiriyani, D. W., Putri, V. R., Yusuf, M., \& Arifin, M. B. (2014). Land Grabbing: Bibliografi Beranotasi. (A. Tohari, Ed.). Yogyakarta, Indonesia: STPN Press.

Purbo, S., et al. (2015). Legal Memorandum Kasus Konflik Tanah Bongkoran Wongsorejo, Banyuwangi. Banyuwangi, Indonesia: Author.

Rachman, N. F. (2016). Bersaksi untuk Pembaruan Agraria: Dari Tuntutan Lokal hingga Kecenderungan Global. Yogyakarta, Indonesia: INSISTPress.

Rahardjo, S. (2009). Hukum dan Perilaku: Hidup baik adalah dasar hukum yang baik. Jakarta, Indonesia: Penerbit Buku Kompas.

Republik Indonesia. (1960, September 24). Undang-Undang Republik Indonesia Nomor 5 Tahun 1960 Tentang Peraturan Dasar Pokok-Pokok Agraria. Retrieved from https:/ / peraturan.go.id/common/dokumen/ln/1960/UU0051960.pdf

Republik Indonesia. (1999, September 30). Undang-Undang Republik Indonesia Nomor 41

Tahun 1999 Tentang Kehutanan. Lembaran Negara Republik Indonesia Tahun 1999

Nomor 167. Retrieved from https://peraturan.go.id/common/dokumen/ln/1999/uu411999.pdf

Republik Indonesia. (2002, August 10). Undang-Undang Dasar Negara Republik Indonesia

Tahun 1945. Retrieved from https://peraturan.go.id/common/dokumen/lainlain/1945/UUD1945PerubahanKeempat.pdf

Rosyadi, S., \& Sobandi, K. R. (2014). Relasi Kuasa antara Perhutani dan Masyarakat dalam Pengelolaan Sumberdaya Hutan di Banyumas: Kepentingan Bisnis VS Community Empowerment. Komunitas: International Journal of Indonesian Society and Culture, 6(1), 47-56. https:/ / doi.org/10.15294/komunitas.v6i1.2939

Safitri, M. A., \& Moeliono, T. (Eds.). (2010). Hukum Agraria dan Masyarakat di Indonesia. Jakarta, Indonesia: HuMa, Van Volenhoven Institute, KITLV- Jakarta.

Sampford, C. J. G. (1989). The Disorder of Law: A Critique of Legal Theory. New York, USA: Blackwell Pub.

Simon, R. (2004). Gagasan Gagasan Politik Gramsci. Yogyakarta, Indonesia: Pustaka Pelajar \& IINSISTPress.

Sumardjono, M. S. W. (2018). Pluralisme Hukum: Sumber Daya Alam dan Keadilan dalam Pemanfaatan Tanah Ulayat. Yogyakarta, Indonesia: Fakultas Ilmu Hukum Universitas Gadjah Mada Yogyakarta.

Susanto, A. F. (2010). Ilmu Hukum Non Sistematis: Fondasi Filsafat Pengembangan Ilmu Hukum Indonesia. Yogyakarta, Indonesia: Genta Publishing.

Wahyuni, D. S. (2016, April 4). Pluralisme Hukum dalam Pembangunan Hukum Indonesia: Masalah dan Tantangan Ke Depan. Retrieved from https:/ /eip.or.id/pluralisme-hukumdalam-pembangunan-hukum-indonesia-masalah-dan-tantangan-ke-depan-2/

Warman, K. (2010). Hukum Agraria dalam Masyarakat Majemuk: Dinamika Interaksi Hukum Adat dan Hukum Negara di Sumatra Barat. Jakarta, Indonesia: HuMa.

Wignjosoebroto, S. (2010, February 15). Nenek Minah Tak Curi Cokelat. Kompas. Retrieved from http:/ / cetak.kompas.com/read/2010/02/15/0233147/nenek.minah.tak.curi.cokelat

Wignjosoebroto, S., Andriani, D., Nurtjahyo, L. I., Andiko, Husein, T., Wukak, P. B., \& Safitri, M. A. (2011). Untuk Apa Pluralisme Hukum? Konsep, Regulasi, Negosiasi dalam Konflik Agraria di Indonesia. (M. A. Safitri, Ed.). Jakarta, Indonesia: Epistema Institute, HuMa, Forest People Programme. 


\section{About the Authors}

1. Umar Sholahudin, obtained his Magister degree in Sociology of Law from Universitas Airlangga, Surabaya, Indonesia, in 2011. The author is an Assistant Professor at the Department of Sociology, Faculty of Social and Political Science, Universitas Wijaya Kusuma Surabaya, Indonesia. The author is currently a PhD student in Social Science, Faculty of Social and Political Sciences, Universitas Airlangga, Surabaya, Indonesia.

E-Mail: umar.sholahudin@gmail.com

2. Hotman Siahaan, obtained his Doctoral degree from Universitas Airlangga, Indonesia, in 1996. The author is a Professor at the Department of Sociology, Faculty of Social and Political Sciences, Universitas Airlangga, Indonesia.

E-Mail: $\underline{\text { hmhsiahaan@gmail.com }}$

3. Herlambang Perdana Wiratraman, obtained his Doctoral degree from Leiden University, Netherland, in 2014. The author is an Assistant Professor at the Department of Law and Development Science, Faculty of Law, Universitas Airlangga, Indonesia.

E-Mail: herlambang@afh.unair.ac.id 